\title{
Use of leeches in a case of severe periorbital haematoma
}

\author{
M J Menage, G Wright
}

\begin{abstract}
A case of severe penetrating eye injury and resulting periorbital haematoma is described. Leeches applied to the eyelids enabled examination of the globe to be carried out and improved the surgical approach. Leeches provide a speedy and efficient means of reducing a periorbital haematoma.
\end{abstract}

Leeches have been used clinically for over 2500 years to treat a wide variety of medical conditions, often without any rational explanation, and so leeching has become associated with medicinal quackery. In recent years there has been resurgence of interest in leeches among plastic surgeons who use them, because of their superb decongestant properties, ${ }^{1-3}$ to treat venous congestion in otherwise unsalvable skin flaps and tissue replants. Their use in periorbital haematoma has been described ${ }^{4}$ but is probably not widely known among ophthalmologists.

\section{Case report}

A 49-year-old alcoholic woman presented with a history of a fall during a heavy drinking session some 12 hours previously. She had been carrying a wine glass and had fallen on to the broken glass with her face.

Examination revealed a deep jagged laceration in the left eyebrow with gross lid and periorbital swelling, which prevented adequate examination of the globe. Penetrating injury was suspected, and it was deemed unwise to use excessive force to separate the tense lids, as this might result in expression of intraocular contents through any laceration of the globe.

Intravenous antibiotics were begun and the eyebrow wound was sutured. A large piece of glass was shown in the orbit on CT scan, but the extent of ocular damage could not be clearly seen.

Six leeches were applied to the patient's eyelids (Fig 1). They rapidly reduced the lid and periorbital swelling, and within a few hours the lids could be gently opened, revealing an intact cornea and a total hyphaema. Surgical exploration soon afterwards showed the globe to have been transected equatorially by a large piece of glass, and a primary enucleation was performed.

Infirmary, Magdalen Street, Exeter EX2 4HT $M$ J Menage

G Wright

Correspondence to: Mr M J Menage, FRCS c/o Department of

Ophthalmology, University of Wisconsin-Madison, Clinical Science Center, 600 Highland Avenue, F4/334, Madison, WI 53792, USA.

Accepted for publication 25 April 199 thalmic use of leeches. Even relatively trauma can result in periorbital swelling seve enough to close the affected eye for several days. This is a considerable handicap to the patient which can delay a return to work or other

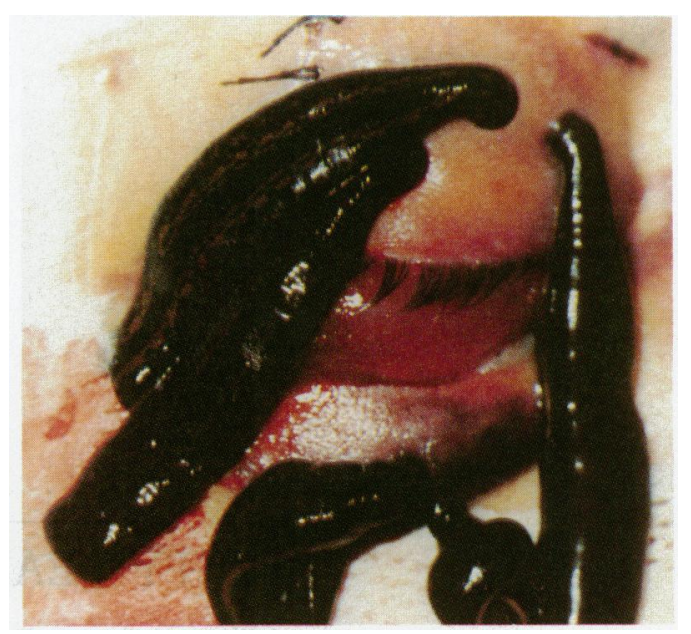

Figure 1 Application of leeches to the swollen eyelids.

activities. Treatment with leeches provides an easy, rapid, and highly efficient means of reducing the periorbital swelling and restoring visual function.

Leech salivary secretions contain a unique and potent anticoagulant called hirudin, a histaminelike vasodilator that promotes local bleeding, a local anaesthetic, and hyaluronidase that promotes the local spread of the other leech salivary secretions into the bite. ${ }^{2}$ A leech can remove up to $15 \mathrm{ml}$ of blood in a single meal, and the bite can continue to bleed for several hours if a dressing is not applied.

The site for leech application should be cleansed with saline to remove all ointments, dried blood, antiseptics, and so on, because these may discourage the leech from biting. The leech should be gently handled with protective gloves, and a drape with a small central hole can be used to direct the leech to the desired area for treatment. Milk or $5 \%$ glucose from a syringe will encourage a reluctant leech to take hold. The leech will usually take between 20 and 40 minutes to finish its meal at which time it will fall off the skin. Leeches can be used again on the same patient, but because of the risk of transferring blood-borne infection are not used again for other patients. They are killed by immersion in $70 \%$ alcohol.

The bacterium Aeromonas hydrophilia lives symbiotically in the gut of the leech. It is recommended that the leech should not be squeezed to remove it forcibly from the patient because to do so may inoculate its stomach contents into the wound. Infections with this organism have been described after leech therapy ${ }^{5}$ but are rare. If necessary the leech can be forced to relinquish its hold by application of salt or by stroking with an alcoholic wipe. 
Hirudo medicinalis is the commonly used species of leech in both Britain and the USA, and is reared on specialist leech farms. If required, stockists will dispatch a consignment by express delivery. In hospitals with large plastic surgery departments, where leeches are sometimes used, the pharmacy will keep a small stock available for immediate use. They are easily kept in a muslin covered glass or plastic tank of water at $20^{\circ} \mathrm{C}$ and will live up to a year without feeding provided the water is changed regularly.
The leeches were obtained by express delivery from Biopharm, a leech farm in Swansea.

We thank Mr J Thomsitt for permission to report on this patient and Ms Karen Jones for photography.

1 Rao P, Bailie FB, Bailey BN. Leechmania in microsurgery. Practitioner 1985; 229: 901-3.

2 Kraemer BA, Korber KE, Aquino TI, Engleman A. Use of leeches in plastic and reconstructive surgery: a review. 7 Reconstr Microsurg 1988; 4: 381-6.

3 Adams SL. The medicinal leech. A page from the annelids of internal medicine. Ann Intern Med 1988; 109: 399-405.

4 Bunker TD. The contemporary use of the medicinal leech. Injury 1981; 12: 430-2.

5 Whitlock MR, O'Hare PM, Sanders R, Morrow NC. The medicinal leech and its use in plastic surgery: a possible cause for infection. Br $\mathcal{F}$ Plast Surg 1983; 36: 240-4.

\section{FIFTY YEARS AGO}

\section{A Fifteenth Century English translation of John of Arderne's de Cura Oculorum By R R James, Woodbridge}

John of Arderne was the first of a long line of celebrated English surgeons. He was born in 1307 and was in practice at Newark-on-Trent from 1349 to 1370. In the latter year he moved to London and in 1377 he wrote his booklet which forms the subject of this paper. We do not know the date of his death, nor do we know where he learnt his art. In one of his writings he describes himself as 'chirurgus inter medicos', and in another as 'cirurgicorum minimus'; but he was evidently in extensive practice and his writings cover a very large field. Perhaps his best work was on fistula-in-ano, piles and rectal cancer. This displays great powers of observation and is well documented with case records. It is decidedly original. The same cannot be said of his treatise on the cure of the eyes; it is for the most part a compilation from the work of others, notably Lanfranc. Ophthalmologically it is worthless, but not without interest.

A precious oynement for bleryed yene and watery. Take a clene holowgh basyne $\&$ anoynt it with inne with buttere dat is not salt and afterward whelve de basyne uppone a vessell dat a mannys uryne is inne, tarte \& hote \& so let it stande stylle tyll it be colde. Afterward that schalbe taken dat clevyd withinne to de basyne de weche is blewysshe of colour \& ther schalbe putte therto a litill of de grece of a caponne $\&$ des schalbe wele medlyd togydere ayene de sounne \& thanne boxe it.

With dis oynement de yelydys schulbe anoyntyd mediocrely with a lytyll slice at eve whane he goth to bedde $\&$ bynde it with a bonde tylle one de morowe.

This oynement cureth beste above alle de medicines in de wordle de bleryed yene \& de waterynge yene as wele in crokedmen as in oder, de weche I have often tymes provyd per certo. And after Johannem Damascenum in alle de sorowe of de yene \& ayenst defawte of de syghte ffurste it behoveth dyligently to consydre wheyther it be of hote cause or of colde, \& yf it be of hote cause furste de mater scalbe deffyed cum surupo acetoso III dayes or IIII. And whanne de mater is dygeste ther schall thane be yoven furste a clystere mollificatyff de mor

That schall devoyd all de body $\&$ dat schall be done with $\frac{\mathrm{v}}{2} \cdot 1 \cdot$ of de a lectuarye made of de juse of rosys \& made scharpe with Dyagredye. And thanne thou mayst sywerly werke with diverse remedyes in de seyd places after that de semeth to spede.

In colde cause de mater also schall furste be deffyed cum oximell diuretico i squillitico \& thane ferdermore de clysterye schalbe yoven as it is aforseyde $\&$ by de morowe alle de body schalbe purgyd cum $\frac{\mathrm{v}}{2}$ from Jorapige Galet. And afterwarde he schall procede foorth sywerly to de places of remedy \& spede wele ...

Here ends the Ms. of the cure of the eyes. tThe hierapicra of Galen.

To my regret I have not been able to compare the proof with the original, and so some errors in 15th century spelling have probably crept in Brf Ophthalmol 1941; 25: 526-35. 